
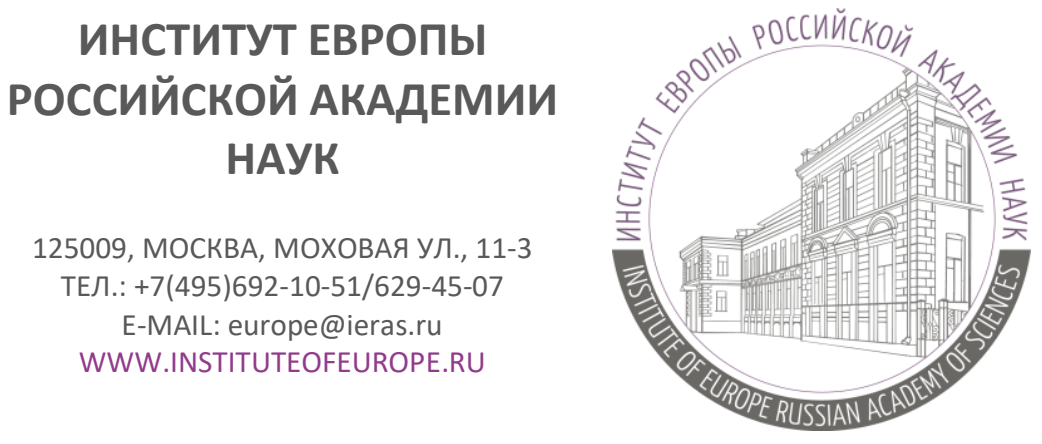

125009, MOSCOW, MOKHOVAYA STR., 11-3

TEL.: +7(495)692-10-51/629-45-07

E-MAIL: europe-ins@mail.ru WWW.INSTITUTEOFEUROPE.RU

\author{
Аналитическая записка №14, 2020 (№197) ${ }^{1}$
}

\title{
Европейский союз: ограничение передвижения граждан как средство борьбы с COVID-19
}

\section{Ольга Юрьевна Потемкина} доктор политических наук, главный научный сотрудник, заведующая Отделом
исследований европейской интеграции Института Европы РАН

\begin{abstract}
Аннотация. Автор анализирует три группь мер, предпринимаемых Брюсселем для борьбы с пандемией коронавируса COVID-19: восстановление контроля на внутренних границах, запрет на передвижение внутри ЕС и Шенгенской зоны; ограничение или запрет на пересечение внешних грании Евросоюза гражданами третьих стран. Изначально лидеры ЕС не намеревались вводить подобные меры и призвали государства-члены к координации действий лишь после того, как те стали вводить ограничения в одностороннем порядке. Законность вводимых запретов основана на ряде законодательных актов EC, но реализация предложенных мер на практике представляется весьма трудным делом.
\end{abstract}

Ключевые слова: коронавирус, восстановление пограничного контроля, закрытие грании, Шенгенский кодекс, запрет на поездки, ограничения свободы передвижения лии.

Ограничение свободы передвижения граждан посредством закрытия как внешних, так и внутренних границ стало одним из политических приоритетов Евросоюза, важной мерой противодействия пандемии коронавируса COVID-19. Регулирование пограничного режима во многих странах мира сыграло важную роль в этой борьбе, и

\footnotetext{
${ }^{1}$ DOI: http://doi.org/10.15211/analytics 142020
} 
не только с точки зрения усиления полицейского и медицинского контроля как преграды распространению вируса. Так, Президент США Дональд Трамп всегда хорошо использовал символический потенциал границ для укрепления национальной идентичности, особенно в кризисные времена, когда население страны чувствует себя под угрозой.

12 марта Трамп издал Указ о запрете на 30 дней доступа в США для иностранцев, посещавших ЕС в предыдущие 14 дней. Евросоюз изначально стремился сохранять открытые границы и не намеревался следовать примеру США. В совместном заявлении от 12 марта Председатель Комиссии ЕС (ЕК) Урсула фон дер Ляйен и Председатель Совета ЕС Шарль Мишель осудили решение Вашингтона. Однако уже 17 марта Европейский Совет на своем саммите единогласно согласился с масштабными ограничениями на поездки в Шенгенскую зону. Любые «несущественные» перемещения через внешние границы ЕС были приостановлены.

Этот поворот последовал за всплеском политической активности государств-членов, направленной на борьбу с пандемией, включая введение временного пограничного контроля и запрета на въезд между несколькими странами ЕС. Все больше правительств в одностороннем порядке восстанавливали внутренний пограничный контроль, вводили ограничения на передвижение определенных видов транспорта и поездок граждан, чем застали врасплох руководство ЕС. Попытавшись сохранить открытые границы в первые недели марта, ЕК была вынуждена сменить курс и признать законность пограничного контроля, попытавшись смягчить его воздействие путем принятия руководящих указаний.

В ответ на пандемию Евросоюз и государства-члены предприняли широкий спектр мер, которые можно условно разделить на три группы: временное восстановление контроля на внутренних границах; запрет на передвижение внутри ЕС и Шенгенской зоны; ограничения или запрет на пересечение внешних границ ЕС гражданами третьих стран.

\section{Временное восстановление контроля на внутренних границах ЕС}

Восстановление пограничного контроля не тождественно закрытию границ - важно различать проверки при их пересечении и ограничения на поездки. Первые в нынешней ситуации не столь проблематичны, но вторые беспрецедентны и ставят важные вопросы правового и этического характера.

Лидерам ЕС пришлось расстаться с надеждой на сохранение шенгенского пространства без границ, когда Австрия, сославшись на ст. 28 Шенгенского кодекса и уведомив Комиссию, 11 марта ввела контроль на границе с Италией, а за ней последовало несколько других стран. ЕК была вынуждена провести видеоконференцию с членами Шенгенской зоны и ассоциированными странами, которые представили меры, принимаемые на пограничных пунктах для выявления пассажиров из групп риска, проверки их температуры и информирования путешественников. 
16 марта Комиссия обнародовала «Руководящие принципы координации действий государств-членов по восстановлению контроля на внутренних границах в пределах Шенгенской зоны свободного передвижения людей» (далее - «Руководящие принципы») $)^{2}$. Главная идея документа - необходимо поддерживать функционирование внутреннего рынка ЕC, а меры контроля, вводимые государствами-членами против распространения COVID-19, должны быть «скоординированными, эффективными и пропорциональными». Будучи инструментом «мягкого права», «Руководящие принципы», тем не менее, содержали не только рекомендации государствам-членам ЕС для обеспечения общего подхода к проверкам на границах, но и список правовых стандартов соответствия национальных мер законодательству ЕС.

Брюссель призвал национальные правительства координировать свои действия с соседними странами и информировать друг друга о вводимых мерах, подпадающих под действие ст. 25 -35 Шенгенского кодекса, поскольку пандемия коронавируса может рассматриваться как «серьезная угроза государственной политике», требующая немедленных действий ${ }^{3}$. Проверки на границах были восстановлены на 10 дней, а потом продлены еще на два месяца. В «Руководящих принципах» ЕК сделала оговорку: медицинские проверки на внутренних границах не означают необходимости восстановления пограничного контроля.

В отличие от ситуации с миграционным кризисом, сегодня законность восстановления пограничного контроля не подвергается сомнению, хотя не все государства-члены уведомили ЕК о своих намерениях, фактически нарушив положения Шенгенского кодекса. К концу марта 15 стран восстановили контроль на внутренних границах: 13 стран ЕС (Австрия, Бельгия, Венгрия, Дания, Германия, Испания, Литва, Польша, Португалия, Финляндия, Франция, Чешская Республика, Эстония), а также Швейцария и Норвегия. Почти все страны ЕС проводят медицинский контроль населения в приграничных районах и должны еженедельно информировать ЕК и другие государства-члены о его результатах.

В качестве символического шага по усилению чувства закрытости границы на некоторых участках швейцарско-германской границы в настоящее время восстанавливаются пограничные заграждения. Однако эта неприятная для местных жителей мера ничтожно мала по сравнению с жесткими ограничениями свободы передвижения.

\section{Запреты на передвижение внутри ЕС и Шенгенской зоны}

\footnotetext{
2 "COVID-19: Guidelines for border management measures to protect health and ensure the availability of goods and essential services" (C(2020) 1753 final). https://ec.europa.eu/home-affairs/sites/homeaffairs/files/what-wedo/policies/european-agenda-migration/20200316_covid-19-guidelines-for-border-management.pdf _ (дата обращения: 7.04.2020)

${ }^{3}$ Regulation (EU) 2016/399 of the European Parliament and of the Council of 9 March 2016 on a Union Code on the rules governing the movement of persons across borders (Schengen Borders Code). Official Journal of the European Union L 77. 23.03.2016. Arts. 25-35.
} 
Пограничный контроль еще не подразумевает запрет на передвижение людей через границы. Однако с началом эпидемии многие государства-члены приняли решение не впускать жителей других стран ЕС, особенно тех, которые в наибольшей степени поражены вирусом. Беспрецедентным нововведением стали запреты, установленные рядом государств ЕС на поездки. 13 марта Хорватия ввела запрет для граждан 12 стран ЕС. Чехия 12 марта запретила въезд всем иностранцам, кроме резидентов, проживающих в стране длительное время; аналогичное решение 12 марта приняла и Венгрия. Чрезвычайные меры, соответствующие почти полному закрытию границ, ввели Польша (15 марта) и Эстония (17 марта), сделав исключение только для транзитных пассажиров. Однако даже граждане стран Балтии были заблокированы на германо-польской границе: после отказа Варшавы в транзите их пришлось вывозить по морю. Норвегия допустила свободное передвижение граждан Северного паспортного союза, полностью закрыв границу для всех остальных.

Во многих странах, в том числе в США, запреты на поездки находятся в компетенции исполнительной власти, а в ЕС мобильность в рамках Единого внутреннего рынка и шенгенской зоны регулируется наднациональным законодательством. Гражданам ЕС гарантировано свободное трансграничное передвижение, его ограничение подлежит рассмотрению Судом ЕС. Но в исключительных случаях государства-члены могут прибегать к чрезвычайным мерам, при этом не нарушая существующих правовых норм.

Несомненно, Брюссель и другие столицы могут квалифицировать коронавирус как «болезнь с потенциалом эпидемии», что служит оправданием для введения ограничений в соответствии со статьей 29 Директивы о свободном передвижении граждан $\mathrm{EC}^{4}$. Тем не менее, ЕК призвала государства-члены соблюдать обязательства по Директиве, касающиеся принципов пропорциональности и соразмерности; не препятствовать возвращению граждан ЕС домой, а медицинским работникам и занятым в пищевой промышленности осуществлять свою профессиональную деятельность.

\section{Ограничения или запреты на поездки граждан третьих стран}

В вопросе закрытия внешних границ ЕС, несмотря на изначальное осуждение решений Трампа, Совет ЕС в конце концов также последовал примеру США. Об этом решении широкая общественность узнала 16 марта из речи президента Франции Э. Макрона. Объявив о «тотальной изоляции», он квалифицировал ситуацию как «Мы на войне» и проинформировал о запрете на въезд всех граждан третьих стран с 17 марта. По свидетельству ряда источников, именно Макрон убедил руководство ЕС закрыть внешнюю границу в ответ на действия США и рост числа односторонних мер

\footnotetext{
${ }^{4}$ Directive 2004/38/EC of the European Parliament and of the Council of 29 April 2004 on the right of citizens of the Union and their family members to move and reside freely within the territory of the Member States amending Regulation (EEC) No 1612/68. Official Journal of the European Union L 158, 30.4.2004. P. 77-123.
} 
правительств государств-членов по восстановлению пограничного контроля внутри $\mathrm{EC}^{5}$.

16 марта Комиссия предложила в масштабах всего ЕС ввести «ограничение на несущественные поездки» ${ }^{6}$, которое Европейский Совет подтвердил днем позже. Если считать, что эпидемия коронавируса представляет угрозу «общественному здоровью», то основанием для такого решения служат ст. 6(1) (е) и 8(2) Шенгенского кодекса. При этом эксперты обращают внимание на ст. 14 (3) - она требует обоснованного решения о запрете на въезд в соответствии со стандартной формой и предусматривает право на обжалование отказа во въезде, что в сегодняшней ситуации вряд ли реализуемо ${ }^{7}$

Государства-члены ЕС и ассоциированные страны Шенгенской зоны получили разрешение отказывать во въезде на внешних границах «гражданам третьих стран, имеющим симптомы заболевания или особенно подверженным риску заражения и представляющим угрозу общественному здоровью». В то же время страны ЕС должны разрешить въезд своим гражданам и гражданам третьих стран, легально проживающим на их территории.

Комиссия в рамках «механизма гражданской защиты» рекомендовала сделать исключение для довольно широкой категории населения: медицинских работников, специалистов по уходу за пожилыми людьми, приграничных работников, исследователей в области здравоохранения; перевозчиков грузов, дипломатов, сотрудников международных и гуманитарных организаций, военных, транзитных пассажиров и путешествующих по чрезвычайным семейным обстоятельствам; лиц, нуждающихся в международной защите, а также возвращающихся на родину в ЕС, для чего используется «механизм гражданской защиты». Первой этот механизм в середине марта применила Австрия, а в начале апреля он был запущен на всей территории ЕС. В этой связи ЕК призвала страны ЕС обеспечить возвращение своих граждан и не препятствовать проезду на родину жителей других стран.

К концу марта все государства ЕС (исключая Ирландию), а также ассоциированные шенгенские страны ввели ограничения на международные (в том числе, внутри шенгенской зоны) пассажирские перевозки. 30 марта Комиссия приняла рекомендации по применению временных ограничений на поездки и содействию репатриации граждан из всех стран мира. Руководство было разработано совместно с Европейским агентством пограничной и береговой охраны (Frontex) при поддержке Европейского центра профилактики и контроля заболеваний (ECDC) и Европола ${ }^{8}$. В дополнение к прежним рекомендациям в Руководстве предлагалось ограничить въезд лиц, нуждающихся в международной защите, случаями, когда необходимо соблюсти

\footnotetext{
5 "Emmanuel Macron on coronavirus: "We're at war"”, Politico.eu, 16 March 2020, https://www.politico.eu/article/emmanuelmacron-on-coronavirus-were-at-war/. (дата обращения: 7.04.2020)

${ }^{6}$ Communication from the Commission to the European Parliament, the European Council and the Council. COVID-19: Temporary Restriction on Non-Essential Travel to the EU. COM/2020/115 final

7 Thym D. Travel Bans in Europe: A Legal Appraisal (Part I) http://eumigrationlawblog.eu/travel-bans-ineurope-a-legal-appraisal-part-i/ (дата обращения: 7.04.2020)

8 Communication from the Commission. COVID-19. Guidance on the implementation of the temporary restriction on non-essential travel to the EU, on the facilitation of transit arrangements for the repatriation of EU citizens, and on the effects on visa policy. Brussels, 30.3.2020 C(2020) 2050 final
} 
принцип невыдворения, что позволяет государствам-членам отсылать лиц, ищущих убежища, в «безопасные страны» транзита или происхождения 9 .

\section{Выводы}

Ситуация в Евросоюзе представляет собой сложное переплетение параллельных действий национальных режимов ограничения въезда и выезда граждан и значительных расхождений условий перемещения внутри Шенгенской зоны. Введение внутреннего пограничного контроля и запретов на поездки уже привело к серьезным нарушениям в международном и внутриевропейском товарообороте и передвижении граждан.

Реализация мер, предложенных Комиссией и введенных государствами-членами в соответствии с решением Совета ЕС, вылилась в чрезвычайно сложный процесс, с длинными очередями и долгим ожиданием, что существенно ограничило свободу передвижения людей и товаров. В результате, у пограничников остается слишком мало времени, чтобы понять, относится ли поездка проверяемого к «существенным» и подлинные ли документы он предъявляет. За очень короткое время оказалось невозможным воспользоваться информационными системами ЕС, как рекомендовал Брюссель.

Даже в случае некоторого улучшения ситуации, можно предположить, что пограничный контроль и ограничение поездок граждан останутся главным средством борьбы с распространением инфекции. Люди попали в ловушку непоследовательных и перекрывающих друг друга национальных ограничений, при этом многие испытывали трудности на пути возвращения в свои страны.

Лидеры Евросоюза и государств-членов принимали решения в состоянии чрезвычайных ситуаций и в крайне короткие сроки - у политиков и экспертов не было времени на тщательные предварительные расчеты и размышления о перспективах функционирования Единого внутреннего рынка и Шенгенского пространства. В последующие недели рекомендации, по-видимому, будут корректироваться на основе анализа хода реализации предложенных мер, а также оценок со стороны юристов и представителей НПО итогов беспрецедентных запретов на поездки и закрытие границ.

Для России, сталкивающейся с теми же проблемами, что и Евросоюз, важно отслеживать и анализировать предлагаемые и реализуемые меры противодействия COVID-19, в том числе механизмы ограничения свободы передвижения граждан. Положительный и отрицательный опыт ЕС интересен и с точки зрения отношений РФ с ее партнерами по Евразийскому экономическому союзу.

Annotation. The author analyses three groups of measures the EU has taken to counter the spread of COVID-19 pandemic: reintroduction of internal border control, intra-EU travel bans, restrictions or

\footnotetext{
${ }^{9}$ Carrera S., Ngo Chun Luk. Love thy neighbour? Coronavirus politics and their impact on EU freedoms and rule of law in the Schengen Area. Brussels, CEPS Paper, No. 2020-04, April 2020, P.21.
} 
bans on entering the EU. The EU leaders initially did not intend to impose such measures and called upon Member States to coordinate their actions only when they started imposing restrictions unilaterally. These bans are legitimate by a number of EU legal acts, but their practical implementation will be very difficult.

Key words: COVID-2019, reintroduction of border control, borders closure, Schengen code, travel bans, restrictions of free movement of people.

Дата выпуска: 10 апреля 2020 года.

Материал доступен для скачивания по адресу: www.instituteofeurope.ru/publications/analytics 